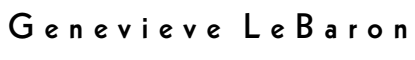

Adrienne Roberts

\title{
Toward a Feminist Political Economy of Capitalism and Carcerality
}

$\mathbf{n}$ his discussion of the violent social transformations associated with the transition to capitalism-what he referred to as the "primitive accumulation" of capital-Karl Marx argued that in contrast with liberal narratives that describe the transition to capitalism as a spontaneous and relatively peaceful process, this historical shift was intricately tied up with relations of force and social struggle ([1867] 1990, 873). Rather than occurring naturally, Marx argued, "capital comes dripping from head to toe, from every pore, with blood and dirt" (874). Taking this line of argument forward in this article, we argue that in the contemporary era the reproduction and extension of capitalism continues to involve relations of violence, coercion, and constraint.

Rather than simply focusing on the violence associated with capitalism, we attempt to highlight the broader disciplinary mechanisms and relations of unfreedom through which capitalism is sustained and reproduced, or what we describe as capitalist relations of carcerality. While we understand these mechanisms and relations to be part of the longue durée of capitalism and therefore too expansive and complex to be fully documented here, our goal in this article is to capture two crucial dimensions of contemporary carcerality: the various ways in which people's current and future life choices and possibilities are being locked into hierarchical and unfree capitalist social relations and, further, the ways in which the social and physical mobility of certain sectors of the population are being constrained through these relations. Focusing on the United States, we argue that, in the contemporary neoliberal era, carceral strategies have become an increasingly central means of locking growing numbers of individuals into dependence on the capitalist market and of containing the contradictions,

Many thanks to Sébastien Rioux for insightful comments on an earlier draft of this article, as well as to the Social Sciences and Humanities Research Council of Canada and the Ontario Graduate Scholarship Program for research funding.

[Signs: Journal of Women in Culture and Society 2010, vol. 36, no. 1]

(c) 2010 by The University of Chicago. All rights reserved. 0097-9740/2010/3601-0002\$10.00 
insecurities, and resistances generated by shifting relations of production and social reproduction. Drawing on a range of feminist scholarship, we also argue that rather than being experienced uniformly, carceral relations are informed by and reproductive of various hierarchies, including those based on class, gender, and race.

While carcerality involves many institutions and social relations, this article focuses on three spaces—prisons, debt, and households—arguing that all three spaces can be conceived as carceral since each involves disciplinary mechanisms that operate to lock people's current and future life choices and possibilities into unequal and unfree capitalist social relations and to limit their social and physical mobility within these relations. While ours is far from a comprehensive account of carcerality, which is multifaceted and complex, in documenting these overlapping spaces and the relations surrounding them, we attempt to create an assemblage demonstrating that carceral relations are present at various sites and scales and permeate the interrelated relations of production and social reproduction. The selection of these three spaces is also a means of drawing attention to the interplay between states, markets, and households in the creation and reproduction of carceral relations. For instance, in the third section of our article, we argue that while the U.S. government has increasingly relied on police and prisons to govern social marginality, this cannot be separated from shifts in the broader political economy that have increased the insecurity of particular segments of the population. In addition, markets are increasingly implicated in carceral relations through the privatization of prisons and related services. In the fourth section, we argue that the U.S. government plays a central role in fueling the proliferation of debt among American families, creating market-based carceral relations. In the fifth section, we point to the ways in which shifts in labor market trends and social provisioning have created carceral relations within households for many domestic workers. The state is implicated in this process since it has actively promoted the employment of paid domestic workers by drastically reducing public forms of provisioning and by designing immigration policies that promote temporary foreign migrant care work to address this reduction. ${ }^{1}$ In and surrounding all three spaces (prisons,

\footnotetext{
${ }^{1}$ In contrast to strictly Foucauldian accounts that characterize the power exerted under neoliberalism as primarily disciplinary, panoptic, diffuse, and uniformly applied, our analysis highlights the social relations and institutions that are directly coercive, embodied, and unevenly applied. Our analysis is thus heavily focused around the historic role of the state in instantiating and enforcing carcerality. We believe that this emphasis could be complemented by an analysis of the ways in which a diverse range of social forces and forms of power have contributed to the creation and reproduction of carcerality in capitalist society.
} 
debt structures, and households), the carceral relations conditioned by states, markets, and households tend to be directed at the lower classes and particularly at lower-class women, certain racial minorities, and migrants.

Finally, by rooting our analysis of contemporary carcerality in the interplay between states, markets, and households-an interplay that has often composed a central aspect of much feminist political economy (FPE) research-we hope to carve out a heuristic space in FPE to come to a deeper understanding of the centrality of carcerality in capitalism and to explore some of the ways in which carceral relations work to integrate increasingly large numbers of people into the capitalist market while marginalizing others. For the lower classes, capitalism increasingly involves both the penalization of poverty and long-term confinement within it. This is confounded by dynamics of racialization and gendering that can be carceral and confining in themselves. Given the centrality of these dynamics and spaces in upholding, underpinning, and facilitating the intensified power of capital in the contemporary moment, further analysis of carcerality in capitalism is urgently required, and FPE is well equipped to develop this sort of analysis for a number of reasons. ${ }^{2}$ Most important, because it conceives the material foundations of social life as the productive and reproductive activities of everyday life and because its integrated analysis provides the heuristic tools to understand the complex overlaps and interconstitution of social relations, FPE has the most potential to integrate an analysis of carcerality into a study of capitalism.

This article begins with a historical analysis of key trends related to the global shift from the post-World War II era of U.S.-led hegemony to the era of neoliberal supremacy. It emphasizes that an important aspect of this shift has involved the contradictory process of, on the one hand, removing constraints placed on the mobility and accumulation of capital while, on the other hand, increasingly constraining the physical and social mobility of the majority of the world's population. Then, focusing on the U.S. case, we highlight how the exacerbated tension between capital accumulation and social reproduction has contributed to the creation of

\footnotetext{
${ }^{2}$ A central focus of FPE, e.g., has been to document the broader relations of unfreedom that underpin the formal marketplace, such as through examining unfree relations in the household and how these are upheld through market discipline and contribute to the production of hierarchical relations of class and gender (see Picchio 1992; Bakker 2003). FPE scholars have also documented capitalism's violent and coercive relations through empirical case studies of the global sex industries, paid and unpaid domestic work, and, more recently, the prison-industrial complex (see Sassen 2002; Sudbury 2005; Bezanson and Luxton 2006; Gilmore 2007, 2009).
} 
carceral relations in prisons, debt structures, and households, noting some of the ways in which capitalist carcerality pervades daily life for certain sectors of the population.

From hegemony to supremacy: Contradictions, crises, and carcerality In the industrialized countries, the post-World War II economic order was largely based around the Fordist mode of production whereby organized labor was integrated into a system of mass production and consumption. This period was marked by a form of social compromise, often called the "post-War compromise" (Panitch 2004, 19), that included both a domestic consensus that combined labor and welfare interests and an international compromise that included a mediation between national interests and the global order. The social compact between capital and labor meant that labor was given certain material concessions in exchange for its support of capitalism at home and imperial policies abroad. This era of what John Ruggie (1982) has called "embedded liberalism" was underpinned by the idea that an active state was necessary to counter the effects of market failures or, in some cases, the absence of markets entirely. States were committed to fiscal and monetary policies that restricted capital mobility and secured low levels of unemployment.

In the postwar era, social reproduction was organized around the idealized male-breadwinner gender order whereby men were privileged in the economic and political spheres while women were assigned the responsibilities of care and domestic labor. Employers and the Keynesian welfare state also took on some of the costs associated with social reproduction as they supported the family wage and various social services. While the benefits associated with the dominant models of production and social reproduction were not equally distributed and forms of provisioning were highly gendered and racialized (Orloff 1993, 315; O'Connor, Orloff, and Shaver 1999), this era has nonetheless been described as a period of U.S. hegemony since domestic and international relations were largely based on consensual rather than coercive politics. ${ }^{3}$

By the end of the 1970s, however, a series of domestic and international circumstances led to the gradual decline of the postwar order, including a deterioration of hegemonic politics. In the United States, as commercial

\footnotetext{
${ }^{3}$ This is certainly not to suggest, however, that violence and direct forms of coercion were absent during the postwar period in the United States and globally. For example, during this time Latin America experienced its most violent dictatorships, and violence was crucial to the development of nations in the postwar decolonizing contexts.
} 
profits began to decline-and in the face of double-digit inflation, a declining dollar, and large capital outflows at home-forces emerged to challenge the Keynesian-era trends of inward economic development, expansionary welfare policies, and the strong bargaining power of unions. Policies designed to undermine working-class power and combat inflation, such as the "Volker shock" of 1979-82 (Panitch and Gindin 2004, 50), marked the beginning of neoliberal domestic policies, which were initially a political response to domestic gains that had previously been achieved by subordinate classes, gains that, from the perspective of capitalist social forces, had become barriers to accumulation.

By now the story is familiar: facing high levels of debt and rising interest rates, the governments of many countries in the global North and the global South either chose to or were compelled, through the lending conditionalities imposed by international financial institutions, to restructure their economies along the lines of the Washington Consensus. ${ }^{4}$ Restructuring has involved the institutionalization of commitments to fiscal discipline, low levels of inflation, and the privatization of state enterprises. It has also involved the removal of controls placed on the movement of capital and goods and facilitated the ability of corporations to move production overseas in order to exploit cheap labor and loose regulatory regimes. Unions have undergone a discursive and material attack, and labor has become cheaper and increasingly flexible and precarious in form. In addition, states have drastically reduced social and welfare spending, leading to the increasing individualization and privatization of risk.

As a result of these transformations, relations of social reproduction have also been restructured. The reduction of social and welfare spending on the part of businesses and the state has led to the "reprivatization of social reproduction" (Bakker 2003) as more of the work associated with social reproduction has shifted to families, the private sector, or both. Globally, more and more women are entering the workforce, often under highly precarious conditions, and in the industrialized countries, the malebreadwinner gender order has gradually given way to a dual-earner model whereby men and women participate in the paid labor market. In this context, domestic and care work is increasingly being performed by women from the global South, often under highly precarious and ex-

\footnotetext{
${ }^{4}$ The Washington Consensus refers to a set of economic policy prescriptions recommending economic liberalization and the curtailment of social welfare provisions that came to be considered the standard reform package for crisis-ridden developing countries by Washington, DC-based institutions such as the International Monetary Fund, the World Bank, and the U.S. Treasury Department.
} 
ploitative conditions because many countries' immigration laws now involve structural mechanisms that limit the ability of migrants to exert rights.

With the transition to neoliberalism, the state has not retreated but has rather been restructured in ways that privilege capital and the wealthy at the expense of the majority of the population. Indeed, while capital has been given greater freedom and mobility, the same has not been true for most individuals. Rather, physical mobility has been restrained through tightly controlled immigration policies and other means. Social mobility has also been constrained, and levels of inequality have increased within as well as among states. This has occurred along a number of lines, including those of class, gender, and race (McNally 2006, 52-55). Fundamentally, as David Harvey argues, the main substantive achievement of neoliberalism has been to redistribute rather than to generate wealth and income, and much of this has been performed through the use of various violent mechanisms of "accumulation by dispossession" $(2005,159)$.

It is in this context that many scholars have argued that neoliberal globalization has greatly exacerbated the tension between capital accumulation and social reproduction. This tension not only threatens the ability of much of the world's population to sustain itself-what can be understood as an emerging crisis in social reproduction-but also poses problems for the reproduction of capitalism itself since capitalism depends on the continued reproduction of a workforce and a stable social and political order. It is largely as a result of this tension in neoliberalism, and the resistances that such social and economic insecurities generate, that carcerality has become an increasingly prominent feature of neoliberalism. Whereas previously the state managed the tensions and insecurities generated by capitalism through a combination of macroeconomic and social policies, in the contemporary era, carceral social relations and institutions have emerged as the preferred response. That is, rather than addressing the problems associated with poverty, growing inequalities, the hollowing out of inner cities, rising levels of unemployment, precarious working conditions, declining or stagnating wages, and so on through progressive economic and social policies, states and market forces have created a carceral matrix that contains and manages tensions and contradictions and that locks people's current and future life choices and possibilities into unequal and unfree capitalist social relations as well as limits their social and physical mobility within these relations.

Rather than simply operating as a repressive and reactionary strategy, the implementation of carceral relations also has a productive dimension and has been used in the extension and deepening of capitalism globally. 
Indeed, on a global scale neoliberal restructuring has been enacted and sustained through what Julia Sudbury (2005) has called the "global lockdown," or the global expansion of carceral institutions and coercive power that emerged in part to quell resistance to neoliberalism and criminalize alternatives to market dependence (such as drug production and distribution, prostitution, and theft; Sassen 2002). The global lockdown has certainly conditioned resistance in various ways, especially after the September 11, 2001, attacks on the U.S. World Trade Center and the Pentagon, after which resistance has been met with heightened state repression evident in the widespread violent suppression of public protest, law-andorder policing, and skyrocketing imprisonment rates, especially for women and racialized groups around the world (Sudbury 2005; see also McNally 2006, 1-26). However, in the face of the deepening and extension of numerous neoliberal tensions, contradictions, and crises, various forms of resistance have continued to take place on local, national, and global scales, including struggles to democratize economic resources and decision making, revolts over land and water privatization and the commodification of other necessities of life, strike actions against poverty, and struggles for gender equality (McNally 2006, 1-26).

Viewed in this way, global neoliberal restructuring has involved "a strategic shift from the politics of hegemony toward coercion as a form of rule" (Lipman 2006, 62), or what Stephen Gill has called the "politics of supremacy" $(2003,118)$. It is in the context of this shift that carceral relations have become increasingly important, pervading the daily lives of certain sectors of the population. In the sections that follow, we create an assemblage that focuses on three spaces central to daily life in the United States-prisons, debt, and households-drawing attention to the ways in which state and market power overlap to create carceral relations of coercion and confinement for particular people. Building on the FPE tradition, we focus on spaces linked to both production and social reproduction and demonstrate how these relations underpin the functioning and reproduction of capitalism, in part by sustaining race-, class-, and gender-based hierarchies. ${ }^{5}$

\section{Prisons}

The first and most obvious carceral institution operating in American

\footnotetext{
${ }^{5}$ Building on Patricia Hill Collins's (2000) work and the insights of black political economy, we conceive race, gender, and class here less as personal identity categories than as social hierarchies that shape access to mobility, property, and power.
} 
society is the prison. Although critical political economy has generally failed to incorporate prisons into theorizations of contemporary capitalism, these carceral institutions have become increasingly central to the everyday lives of many individuals and social groups. They are therefore key dimensions of capitalist carcerality, becoming increasingly vital to the functioning and reproduction of capital in the U.S. context as they instantiate and secure the marketplace in ways that reproduce class-based, gendered, racialized, and other inequalities and insecurities.

The United States currently leads the world in terms of incarceration rates, with 1 percent of the adult population now locked up in prison or jail (Pew Center 2008, 3). Adding those on probation and parole, one in every thirty-one adults, or 3.2 percent of the population, is under some form of criminal justice supervision (Pew Center 2009, 1). While incarceration rates are rising in other countries as well, the U.S. rate of imprisonment is now six to twelve times that of other advanced industrialized countries (Mosley 2009, 8). Incarceration in the United States has always had a class-based and racial dimension, but during the neoliberal era, class and racial inequalities in prison admission have increased considerably (Western 2006, 75-78). Overall, more than two-thirds of those imprisoned are black or Latino, and at the end of 2007 one in every three black men was under some form of correctional supervision (Pew Center 2009, $5)$. Incarceration trends are also highly gendered, and in recent years women have been incarcerated at a faster rate than men. According to one study, while men's incarceration rate rose by 300 percent between 1980 and 2000, women's incarceration rate rose by an even more drastic 650 percent (Haney 2004, 334). Again, these trends are not restricted to the United States since poor, young, racialized women and girls are among the fastest-growing prison populations worldwide (Sudbury 2005, xiv).

Rather than responding to increases in crime, in the neoliberal erain the United States and elsewhere-class-based, racialized, and gendered patterns of criminalization and incarceration have emerged as "the preferred public response to the problems created by poverty" (Gilmore $2009,79)$. That is, in contrast to the postwar approach to the governance of social marginality through welfare and social assistance, criminalization and incarceration have emerged as a primary means of managing the contradictions and insecurities generated by neoliberal social and economic policies. As these policies are informed by and operate in ways that reproduce class-based, gendered, racialized, and other inequalities and insecurities, so too are the carceral relations that have emerged to deal with them. 
For instance, feminist political economists have extensively argued, as neoliberal social and economic policies have intensified the demands placed on women as caregivers in the family and community and as workers in a highly precarious, gendered, and sex-segregated labor market, they have contributed to the feminization of poverty and to an emerging crisis in social reproduction (Bakker 2003, 79; Vosko 2006). However, FPE has been less attentive to the ways in which this gendered insecurity has led some women to engage in criminalized activities. Yet there is ample evidence to suggest that gendered insecurity under neoliberalism is a key factor driving the growing incarceration of women. ${ }^{6}$ For example, in one study, the majority of mothers interviewed-an estimated 70 percent of women in jail have minor children-correlated their criminal activity with their economic situation, which included the entitlement of needy single mothers to a meager annual cash benefit of $\$ 3,345$ and a lack of low-cost housing, child care, and medical services for single mothers, among others (Ferraro and Moe 2003, 18). Studies have also identified both a positive correlation between levels of unemployment and rates of imprisonment (Wacquant 2001; Gilmore 2007) and a negative correlation between welfare spending and rates of incarceration (Beckett and Western 2001). In this context, it is not surprising that women, particularly poor and racialized women, who are disproportionately employed in precarious forms of work and dependent on welfare services, constitute the fastest-growing segment of the prison population.

The racialized patterns of incarceration in the United States can similarly be linked to racialized insecurities generated by shifting capitalist relations of production and social reproduction. As sociologist Loïc Wacquant $(2001,2002)$ has argued, the trend toward mass imprisonment in the United States is directly related to the shift away from the welfare management of poverty and race relations and toward the warehousing of precarious and deproletarianized factions of the black working class (who are unable or unwilling to find employment owing to a range of factors, including the loss of manufacturing jobs, employer discrimination, competition from immigrants, etc.) in prisons and other carceral institutions. In his words, after forsaking the Fordist-Keynesian social compact in the mid-1970s, "the United States launched into a unique sociohistorical experiment: the incipient replacement of the welfare regulation of poverty and of the urban disorders spawned by mounting insecurity and racial strife by its penal management via the police, courts, and correctional system" $(2002,19)$.

\footnotetext{
${ }^{6}$ See Heimer (2000) for a review of this literature.
} 
Thus, rather than being concerned with crime control per se, the U.S. government has employed a strategy of policing and incarceration to contain the social disorders, insecurities, and resistances generated by neoliberalism, including highly unequal patterns of capitalist accumulation, the rise of precarious forms of labor, and the disintegration of Keynesian-era social welfare protections. As the tension between capital accumulation and neoliberal restructuring has been exacerbated by the shift of resources away from social-service-oriented institutions, the inevitable fallout has been contained through the carceral management of the classed, gendered, and racialized bodies that have been marginalized by this social order.

It is important to note that rather than simply responding to insecurities generated by neoliberalism, carceral strategies have also been central in instantiating and securing the capitalist market. For instance, in the United States, the majority of prisoners are not incarcerated for violent offenses (which accounts for only two in ten prisoners) but for a range of so-called disorderly and criminalized offenses, many of which can be understood as attempts to secure one's livelihood outside of the formal marketplace through selling drugs, prostitution, or panhandling, for example (Parenti 1999, 217, 239; Western 2006, 38). Such carceral strategies are not new but rather can be traced back to the modern police forces that emerged in industrialized countries in the nineteenth century and played a central role in the fabrication of the capitalist social order (Neocleous 2000).

In addition to constraining the physical mobility of individuals, prisons can be understood as carceral in the sense that they restrict the social mobility of many individuals and families and help to (re)integrate people into capitalist relations of production and social reproduction that are themselves hierarchical, coercive, and filled with gendered and other meanings. Generally ignored by critical political economists, former prisoners are among those who face some of the harshest discrimination in the labor market, receiving lower wages on average than others with similar backgrounds (Western and Beckett 1999; Western 2006). In addition, a number of policies restrict those convicted of certain offenses-including, in many instances, drug felonies under the three-strikes laws (which require courts to impose mandatory sentences on individuals convicted of three serious offenses) - from accessing education grants, student loans, welfare benefits, food stamps, veteran benefits, Medicaid, and public housing (Wacquant 2001, 119-20; Bohrman and Murakawa 2005, 119-21). Debts incurred in prison have also become increasingly common, with some incarcerated parents leaving prison owing more than $\$ 20,000$, mostly in child support arrears (McLean and Thompson 2007, 2). In this 
way, the carceral relations of prisons overlap with the carceral relations of debt explored in the following section.

Insofar as the U.S. government plays a central role in creating and sustaining prisons as carceral spaces, so too does the market, particularly with the growth of prison labor and the increasing privatization of prison services. For instance, neoliberal legislation has facilitated the corporate use of prisoners' labor power, which then (re)integrates them into unfree capitalist relations of production, offering capital the opportunity to exploit the labor of primarily poor and racialized prisoners while simultaneously disempowering labor outside the prison because low-skilled workers are laid off when their jobs are moved behind bars (Chang and Thompkins 2002; LeBaron 2008). Prisons are also increasingly being run as capitalist enterprises, with the privatization and commodification of everything from the provisioning of food and management services, infirmary items, and guards to the prisons themselves (Parenti 1999; Bohrman and Murakawa 2005). This further links capital accumulation to mass imprisonment, offering an incentive for certain factions of capital—and labor (i.e., prison guards) - to resist a shift away from the trend of mass imprisonment. Despite such trends, there is significant resistance in the United States and globally to mass imprisonment, and struggles are being waged on numerous fronts by current and former prisoners, their families, and various other antipoverty and antiracism activists. ${ }^{7}$ Perhaps ironically, the contemporary financial crisis has provided a new opportunity for resistance efforts since many states are facing massive budget shortfalls, and prisons costs - which amount to over $\$ 60$ billion a year-are undergoing serious scrutiny from those on both sides of the political spectrum (Pew Center 2009, 2-3).

In sum, as criminalization and incarceration have emerged as the primary means of managing the contradictions and insecurities generated by neoliberal social and economic policies, the prison has been integral to class-based, gendered, and racialized relations of capitalist production and social reproduction and a crucial dimension of the carcerality that pervades daily life for certain sectors of the population.

\section{Debt prisons}

While surging incarceration rates are a central dimension of carcerality in

${ }^{7}$ A list of many of these organizations and various ongoing antiprison struggles can be found on the Prison Activist Resource Center Web site, http://www.prisonactivist.org. 
the neoliberal era, carcerality also involves a range of more structural and indirect relations that lock people's current and future life choices and possibilities into unequal and unfree capitalist social relations and limit their social and physical mobility within these relations. Debt structures are a primary example of such relations because they have increasingly forced individuals into dependence on the market, often under highly inequitable terms. Indeed, since the 1970s debt has become an increasingly important part of the everyday lives and social reproduction of growing sectors of the American population. For instance, it has been estimated that in 2008, the average American household carried over $\$ 8,500$ in credit card debt, up almost 15 percent from 2000 (Morgenson 2008). Overall, household debt, including mortgages and credit cards, amounts to 19 percent of total household assets, up from 13 percent in 1980 (Morgenson 2008). With debt-fueled consumer expenditure accounting for over two-thirds of the gross domestic product (Montgomerie 2009, 3 ), social relations of indebtedness have crucially underpinned the functioning and reproduction of capitalism in the neoliberal period. This explosion in consumer and household debt is part of a broader process that has taken place over the past few decades in many countries, whereby the microlevel actions of individuals are increasingly linked to the global financial structure (Froud, Leaver, and Williams 2007; Langley 2008). As part of this process, many aspects of social reproduction have also been linked to global finance and consequently to its tensions, contradictions, and crises.

While the causes for the rise of financialization are contested and complex and it is beyond the scope of this work to explore them in detail, it is important to note here that the growth of finance and, concomitantly, growing indebtedness has been actively supported by the U.S. government, which over the past few decades has removed various regulations put in place after the Great Depression to avoid future financial crises and has been remiss in passing new regulations pertaining to the new financial instruments that have emerged in recent years. The state has also actively promoted the boom in borrowing and lending by ensuring access to cheap money (through low interest rates, etc.) and by launching massive public campaigns, such as George W. Bush's ownership society campaign, designed to convince consumers of the benefits associated with integration into markets through home ownership, privatized pension plans, and other means.

The extension of home mortgages and various other instruments of debt in the 1980s and 1990s was related to the rise of new social forces that benefited from financial accumulation and to the relative decline in 
profitability of many postwar industries. However, the extension of credit was also used as a means of dealing with the negative impacts of neoliberal social and economic policies, and debt became the primary means of maintaining standards of living and securing livelihoods. For instance, studies indicate that since the early 1970s, for those in the lower 80 percent of the income distribution, borrowing has occurred as a direct result of the need to maintain living standards in the face of stagnating real incomes and the corresponding rise in real living costs, especially for housing (Pollin 1990, 1). This "necessitous" borrowing (1) has not been accompanied by any parallel growth in financial assets and, with unsecured debt surpassing income levels each year since 1992 (Montgomerie 2009), has led to a situation in which middle- and working-class individuals' and families' social reproduction strategies are increasingly dependent on various instruments of debt. Thus, debt has emerged as a means of addressing the insecurities generated by neoliberal social and economic policies, and the state has actively facilitated the extension of debt as a means of managing the emerging tension between new forms of capital accumulation and social reproduction under neoliberalism.

With this shift, debt relations have taken on a carceral form, locking increasing numbers of people into dependence on financial markets in order to secure their livelihood. In addition, as with the institutional prison, carceral relations of debt have locked the life choices and possibilities of classed, gendered, and racialized bodies into capitalist social relations that are highly unequal and tend to perpetuate social divisions and inequalities. Subprime mortgage lending in the United States offers one of the most obvious examples of this trend. As growing numbers of Americans bought their own homes, they were not integrated into a neutral economic sphere in which they could interact with other individuals on formally equal terms. Rather, many people were integrated into the market on highly unequal terms, deemed to be risky borrowers and thus offered high-interest loans or subprime loans at variable interest rates (Fishbein and Woodall 2006, 3). Although liberal economics suggests that such assessments of risk are based on abstract mathematical calculations, numerous studies have shown that they are in fact highly informed by gender and race. For instance, studies have found that, despite having slightly higher credit scores than men, women are around 30 percent more likely than men to receive subprime mortgages. This disparity exists in all mortgage products, spans all income levels, and actually increases as levels of income rise (Fishbein and Woodall 2006).

African American and Latino borrowers have also received a disproportionate share of subprime loans, and it has been found that borrowers 
of color are over 30 percent more likely to receive higher-rate loans than white borrowers are (Fishbein and Woodall 2006). This is the case even when legitimate risk factors, such as income and property location, are taken into account (Gruenstein, Ernst, and Li 2006). Facing both gendered and racialized discrimination, African American women are integrated into such financial relations on particularly unequal terms. According to one study, an African American woman is 256.1 percent more likely to receive a subprime mortgage than a white man is (Fishbein and Woodall 2006, 3-4).

As the ideal of home ownership was being sold as an empowering and liberating right, if not duty, of all Americans, the reality was that many of them were entering into long-term and highly discriminatory debt obligations. Rather than liberating individuals and families and reducing historical barriers to social mobility, the proliferation of market dependency through debt (as well as the privatization of social security, pension plans, health care, etc.) has tied individuals to an unequal and insecure financial market. One implication of this trend is that it has encouraged the working class to identify with the interests of the capitalist class, which both veils existing class divisions and legitimates the financial market. ${ }^{8}$

However, the deepening of dependency on the market through debt has served to disempower labor and to compel workers to work for longer periods of time, regardless of the pay and conditions involved. For instance, studies have found that labor force participation among older workers has been rising since the early 1990s, partly as a result of increased levels of borrowing for consumption (Munnell and Soto 2008). In many instances, the choice to work for more years of one's life is really not a choice at all but a necessity created by the carceral relations of debt, the privatization of social security, and other trends associated with neoliberalism. Still, economic liberals present this situation as inevitable and irreversible. As Susanne Soederberg explains, "the message is clear: workers are now dependent on the market instead of the state for social protection in their old age; they must therefore work harder and longer to ensure a secure retirement (never mind that wages in the United States

\footnotetext{
${ }^{8}$ To a certain extent, the contemporary global financial crisis has unmasked these divisions, and many people in the United States (and globally) have voiced their opposition to taxpayer-funded financial bailouts for the rich and for large corporations. The wave of foreclosures and evictions that is leaving growing numbers of Americans homeless is also being met with resistance and acts of civil disobedience. So too are the gendered and racist predatory-lending practices that contributed to the crisis and to the reproduction of poverty more broadly.
} 
failed to keep up with levels of productivity growth over the past three decades)" $(2007,96)$.

In addition to being locked into wage-labor relations, with the proliferation of debt many people are also being locked into gendered and racialized hierarchies. The paradox is that the extension of mortgage (and other) lending has a progressive element since it has addressed the historic exclusion of single women and racialized minorities from home ownership in America. However, because they have been incorporated on unequal terms, many of these individuals and families have not been able to use their homes as wealth-building assets to the same extent as white men. In this way, their integration into market relations through mortgage debt has reproduced rather than eliminated gendered and racialized inequalities. Thus, as with the institutional prison, debt can be conceived as a carceral space that limits life choices and possibilities and constrains physical and social mobility. Viewed together, the institutional prison and the debt prison can be understood as social relations of carcerality that, although differing in their degree of direct coercion, are nonetheless part of a broader attempt to manage the contradictions associated with neoliberal restructuring; to address some of the challenges posed to relations of social reproduction; and to (re)integrate individuals into classed, gendered, and racialized capitalist social relations. ${ }^{9}$

\section{The prison of the home}

The household is a third space that can be conceived as carceral since it confines certain people within capitalist social relations and limits social and physical mobility within these relations. On the one hand, the state has redefined social reproduction from a matter of public concern to one of private responsibility, and shifting gender orders and labor markets have involved the integration of many women into the wage labor market on unequal terms. On the other hand, many households have managed the resulting tensions and insecurities by relying on the labor of other often racialized, lower-class, and migrant women. In many instances, these women face considerable coercive constraints, and the relations of the

\footnotetext{
9 Such strategies have a much longer historical lineage than can be outlined here. For instance, debt was (and continues to be) the primary mechanism used to compel governments in the global South to restructure their economic and social policies along neoliberal lines. This process has involved the increasing integration of national economies into global financial circuits and has rendered the lives and livelihoods of many individuals in the global South increasingly dependent on global financial trends.
} 
household take on a carceral form, constraining their physical and social mobility and locking their current and future life possibilities into hierarchical and unfree capitalist social relations. This process has been greatly facilitated by state policies, including the reduction of social spending and the privatization of state enterprises, in addition to the development of immigration policies specifically designed to facilitate the entrance of foreign domestic workers for limited periods of time and under precarious conditions. Thus, insofar as nonfeminist scholars tend to treat households as a separate, private sphere, household relations are shaped to a large extent by socially and historically specific state policies.

In the first case, while many claim that the neoliberal period has increased women's liberation and eliminated many gender-based inequalities, a substantial body of qualitative and quantitative research demonstrates that the surge in labor market activity among women in industrialized countries has been characterized by persisting occupational and industrial segregation and gendered precariousness. It has also involved shifts in the organization and character of social reproduction, including the reintroduction of highly commodified migrant domestic workers as a privatized solution to the social challenges resulting from some women's entry into the labor market. ${ }^{10}$ At the same time, intricately related to economic restructuring, privatization, and the downloading of care work onto individuals and households, neoliberal restructuring has also involved the devolution of federal responsibility for public services related to social reproduction. More specifically, as a wide range of feminist scholars have documented, socially reproductive activities that formerly took place in public spaces such as hospitals, schools, long-term care facilities, and daycare centers, among others, have been relocated into the private household, and women have disproportionately assumed the labor and costs associated with them (Bezanson and Luxton 2006; Vosko 2006). Neoliberalism has therefore entailed the transformation and reconstitution of the household and the relationships and labor within it. ${ }^{11}$

While entrance into the paid labor market has certainly increased the independence and mobility of some women, at the same time new constraints are evident in the lack of choice that many experience in relation to these increased burdens of social reproduction. As some women have subcontracted components of social reproduction to the market, others have had to assume double or triple burdens. In the latter case, for women

${ }^{10}$ See Arat-Koc (2006), Misra, Woodring, and Merz (2006), Pyle (2006), and Cobble (2007).

${ }^{11}$ For a comprehensive analysis of the U.S. context, see Chang (2000). 
and families who cannot afford to subcontract labor to the market, there has been a net increase in women's waged work by compelling them to work more hours-and in many cases work multiple jobs-forcing many to assume a double or triple burden of work. Quantitative and qualitative research indicates that women (often racialized women) are still the most likely to live below the poverty line, and "a whopping 90 percent of those earning less than $\$ 15,000$ annually and over two-thirds of those making under $\$ 25,000$ a year are women" (Lovell, Hartmann, and Weschkul 2007, 36-41). This suggests that the choice to subcontract labor to the market or to take on additional burdens is shaped by gendered, classed, and racialized social relations.

In the former case, and in the context of declining social entitlements and downward pressure on wages, those who can afford it have subcontracted components of social reproduction to the market by hiring livein domestic workers, usually temporary foreign migrant workers who, lacking alternatives, leave their own families in order to care for families in the United States. Far from being exclusive to the U.S. context, industrialized countries' widespread importation of transnational care workers from the global South has been part of a global phenomenon often referred to as the "internationalization of care work" (Misra, Woodring, and Merz 2006, 317), which has been anchored in particular features of the globalization of economies in both the North and the South (Sassen 2002). Far from being a spontaneous, free-market phenomenon, the internationalization of care work has been regulated through restrictive immigration policies and the policing of immigrant populations (Misra, Woodring, and Merz 2006, 317). While in the global North states have institutionalized temporary foreign migrant care work to mediate the contradictions of neoliberalism, which are triggering a crisis in social reproduction, in the global South states have actively promoted the migration of care workers, whose remittances have become central to the social reproduction of many families and have helped to guarantee a flow of foreign currency into their home countries (318).

The U.S. state apparatus has actively promoted the employment of livein domestics as the solution to the burdens of housework and child care among high- and middle-income groups. This strategy has been politically conditioned by the lack of adequate child-care services, and the continuing availability of a cheap and vulnerable source of foreign domestic workers has been institutionalized through coercive and discriminatory labor laws (Arat-Koc 1997). States have presented this individualistic, privatized solution to the crisis of social reproduction as a clear deal for many women who can have professionally rewarding careers without having to give up 
on children. It has also provided jobs for women from the global South, which have become more and more necessary after waves of neoliberal privatization, structural adjustment, and increasing wealth polarization. But given the widespread exploitation, unfreedom, and physical abuses experienced by many migrant domestic workers, this deal is clearly not the win-win situation portrayed by states and capital (e.g., through laborrecruiting agencies and other corporations associated with domestic migrant work). Rather, the surge in labor market activity among women in industrialized countries has relied on carceral constraints for racialized, lower-class, and often migrant women, limiting their social and physical mobility and integrating them into the circuits of capital on unfree and unequal terms.

A range of scholars and community organizations have documented (and struggled to address) the widespread exclusions and unfreedom that characterize live-in migrant domestic work in industrialized countries. In the United States, for example, Human Rights Watch has documented that such workers are commonly paid significantly below the minimum wage, with the median hourly wage at $\$ 2.14$ and some paid as low as $\$ 100$ a month. The median workday is fourteen hours, while many work up to nineteen hours a day and are presumed to be on call at all times (2001, 1-13). In addition, migrant domestic workers often experience significant constraints to their social and physical mobility, as many employers of domestic workers use myriad techniques to limit workers' freedom of movement and perpetuate their social and cultural isolation. For example, employers confiscate workers' passports; deny workers the right to leave the employers' premises after work hours; misrepresent U.S. law, culture, and the dangers of U.S. streets; prohibit workers from speaking with anyone outside the employers' immediate families, either in person or by telephone; and deny workers the right to attend religious services (Arat-Koc 1997; Human Rights Watch 2001). Additionally, domestic workers are often unable to refuse work and are subject to their employers' control over some choices such as where they sleep or what they eat and drink. Furthermore, subject to surveillance and control because they are not citizens of the countries in which they work, and with their vulnerability underpinned and reinforced through disciplinary and highly constraining immigration laws that limit migrants' abilities to exert rights (Parreñas 2001, 1130), domestic workers are often locked into these unfree and hierarchical relations. Perhaps most significantly, the majority of domestic workers in the United States enter with a B-1 visa, meaning they can never legally change employers, and to do so would mean losing their legal immigration status and possibly facing deportation. 
Given these circumstances-and since the inequitable integration of migrant domestic workers into U.S. circuits of capital also involves multiple exclusions from their home places, families, and possibilities for having children, as well as from social entitlements received by U.S. workerssome scholars have argued that domestic workers are neither members of the nation nor citizen-members of the state (Arat-Koc 1997, 56). In the U.S. context, a poignant example of this is the fact that while immigrant women's labor power is desired-and indeed makes possible the maintenance and reproduction of the American labor force at virtually no cost to the U.S. government-their own reproduction, be it biological or social, is not. Biological reproduction is deemed undesirable because it entails the U.S. state having to provide basic needs for raising and training the children of immigrants. While most domestic workers are concerned not to get pregnant because they would lose their jobs, they are also conscious that in many instances they are forfeiting their own chance to have children by remaining migrant domestic workers during their crucial reproductive years (Chang 2000). ${ }^{12}$

In sum, by locking many women's current and future life choices and possibilities into hierarchical and unfree capitalist social relations and constraining physical and social mobility within these relations, households have composed a crucial dimension of capitalist carcerality, underpinning the market, and have (re)integrated individuals into classed, gendered, and racialized capitalist social relations. In contrast to the postwar approach of using welfare and social assistance to meet some of the challenges of social reproduction, the crisis of social reproduction generated by neoliberal social and economic policies has been managed by downloading the costs and labor of social reproduction onto households and by ensuring the continuing availability (through legislation, disciplinary practices, and coercive and discriminatory labor laws) of a cheap and vulnerable source of foreign domestic workers. Rather than solving the problem of gender inequality under neoliberalism, domestic service adds class, racial, and national dimensions to it, increasing inequality among women on a global scale. As Sedef Arat-Koc (1997) has argued, instead of housework being the responsibility of all women, it has become the responsibility of only

${ }^{12}$ As Rhacel Salazar Parreñas explains, by containing the costs of reproduction in sending countries, wages of migrants can be kept to a minimum since migrants do not have the burden of having to afford the greater costs of reproducing their families in host societies. Moreover, by restricting the incorporation of migrants, receiving nations can secure their economies a supply of low-wage workers who can easily be repatriated if the economy slows down $(2001,1134)$. 
some, with subordinate racial, class, and citizenship status, who are employed and supervised by those they liberate from the physical burdens, further stratifying women.

It is important to note that women have not been passive observers of this process but rather have been actively engaged on various fronts. For instance, women's groups in the United States and elsewhere have struggled to protect the social services that were won in previous battles and in some instances to increase state and corporate support for care work. Migrant women are also actively engaged in efforts to protect their basic human rights and to improve social and economic conditions in both sending and receiving societies. Groups such as MIGRANTE International (an international alliance of Filipino migrant organizations) work tirelessly to combat abuses and exploitation and to gain access to welfare services, all of which are necessary for "genuine freedom and democracy." 13

\section{Conclusion}

Now, as in Marx's time, what appears to be an invisible hand guiding people's labor market participation and choices in the United States and elsewhere is, in reality, an iron fist involving the highest incarceration rates in the world, debt structures that deepen and extend market dependency for greater periods of time, and the reorganization of households and relations of social reproduction in ways that create carceral constraints for certain women. As we have argued, rather than promoting universal social and economic mobility, capitalism involves multiple dimensions of carcerality or disciplinary mechanisms and coercive relations through which the market is sustained and reproduced. We have attempted to capture key dimensions of carcerality in the contemporary U.S. context by documenting the ways in which three carceral spaces operate to lock people's current and future life choices and possibilities into unfree and unequal capitalist social relations, as well as to limit their social and physical mobility within these relations.

In the first case, we have argued that carcerality is evident in the social relations surrounding prisons that contain particular marginalized sectors of the population and then operate to (re)integrate largely lower-class and racialized individuals into capitalist social relations on highly inequitable terms. It is also evident in debt structures, which operate like carceral apparatuses to prompt and underpin people's dependence on and submission to market forces and lock them into hierarchical relations of class,

${ }^{13}$ See http://migrante.tripod.com. 
gender, and race. In addition, as some women have supposedly been freed from the household and entered the paid labor market, often on highly inequitable terms, shifting relations of social reproduction have led to the enclosure of other primarily lower-class, racialized, and migrant women.

Rather than occurring in isolation from one another, the carceral relations involved in and surrounding prisons, debt, and households are overlapping and deeply interrelated. As we have attempted to show, rather than affecting abstracted individuals, these layered carceral spaces disproportionately affect and attempt to manage particular groups: poor, racialized, and gendered populations, whose daily lives are increasingly organized by facets of all three of these (and many other) carceral relations and spaces. That is to say, as states and market forces have created a carceral matrix that contains and manages the tensions and contradictions of neoliberalism, it is increasingly the same individuals and households that are drawn in to this matrix. For instance, in many cases, those individuals and families locked into debt are the same individuals and families that are affected by mass imprisonment. Mass imprisonment then plays a role in shaping household relations since the loss of male breadwinners-particularly in African American communities-is often met with increases in the paid and unpaid work performed by female family members. While future research is required to document the interplay between these relations in greater detail, we have tried to capture a key dimension of this by highlighting some ways in which capitalism increasingly involves both the penalization of poverty and long-term confinement within it.

Given the centrality of these dynamics and spaces in upholding, underpinning, and facilitating the market and capitalist social relations, further analysis of capitalist carcerality is urgently required. There is thus a need for both critical and feminist political economy to be able to account for these currents of coercion, constraint, and unfreedom as they relate to, and indeed often underpin, the spread and normalization of capitalism. While this essay has taken some initial steps at conceptualization, we also want to highlight three interrelated trajectories of thought that could be explored as new directions in FPE.

In the first instance, future research could more deeply examine institutions and the crucial roles they play in stabilizing the dominant class, gender, and race/ethnic order. While FPE has certainly grasped the role of households in stabilizing gender orders, it could be fruitfully extended to explore the ways that the prison and debt structures, as well as other institutions and spaces, similarly stabilize and reproduce the dominant class, gender, and race/ethnic orders. Doing so will require the development of a more integrated approach within FPE, focusing on the in- 
terrelations between spheres of production and social reproduction as well as an understanding of gender, class, and race as a series of layered experiences.

In the second, and related, case there is a need to more deeply explore interconnecting modes of coercion, unfreedom, and violence within a capitalist system and the ways that these immobilize, enclose, and create physical, social, and economic barriers to mobility. This requires a historically integrated analysis of the relationships between capital, carcerality, and unfreedom that can comprehend the centralization and reproduction of the market in various contexts, linking the macroglobal to the micropersonal. Methodologically, this might require moving away from linear narratives and toward creating assemblages across time, space, and relations, as this can help us come to a deeper understanding of the different layers and dimensions through which capital is shaping people's daily realities and conditions of existence. ${ }^{14}$

Finally, there is a need to examine historically the role and importance of carceral social relations as a means of quelling resistant and anticapitalist social forces. As the prison section illustrated, when people attempt to resist or are marginalized from market life, there is increasing pressure, and indeed there are coercive structures that constrain and penalize this resistance and integrate people's life choices more deeply into the imperatives and (re)productions of capitalism. This type of analysis has practical consequences since it would recenter carceral spaces as potential sites for resistance against capitalism and could contribute to existing efforts, such as those by INCITE! Women of Color against Violence and other groups, to bring prison abolitionists, workers rights groups, migrant rights groups, and poverty advocacy groups into a broad-based feminist, antiracist, anticapitalist coalition.

Department of Political Science

York University

\section{References}

Arat-Koc, Sedef. 1997. "From 'Mothers of the Nation' to Migrant Workers: Immigration Policies and Domestic Workers in Canadian History." In Not One of the Family: Foreign Domestic Workers in Canada, ed. Abigail B. Bakan and Daiva Stasiulis, 53-80. Toronto: University of Toronto Press.

${ }^{14}$ Ruth Gilmore's essay (2009) "Race, Prisons, and War: Scenes from the History of U.S. Violence" is an excellent example in this regard. 
2006. "Whose Reproduction? Transnational Motherhood and Challenges to Feminist Political Economy." In Bezanson and Luxton 2006, 75-92.

Bakker, Isabella. 2003. "Neoliberal Governance and the Reprivatization of Social Reproduction." In Power, Production, and Social Reproduction: Human In/ Security in the Global Political Economy, ed. Isabella Bakker and Stephen Gill, 66-82. New York: Palgrave Macmillan.

Beckett, Katherine, and Bruce Western. 2001. "Governing Social Marginality: Welfare, Incarceration, and the Transformation of State Policy." Punishment and Society 3(1):43-59.

Bezanson, Kate, and Meg Luxton, eds. 2006. Social Reproduction: Feminist Political Economy Challenges Neo-Liberalism. Montreal: McGill-Queen's University Press.

Bohrman, Rebecca, and Naomi Murakawa. 2005. "Remaking Big Government: Immigration and Crime Control in the United States." In Sudbury 2005, 109-26.

Chang, Grace. 2000. Disposable Domestics: Immigrant Women Workers in the Global Economy. Cambridge, MA: South End.

Chang, Tracy F. H., and Douglas E. Thompkins. 2002. "Corporations Go to Prison: The Expansion of Corporate Power in the Correctional Industry." Labor Studies Journal 27(1):45-69.

Cobble, Dorothy Sue, ed. 2007. The Sex of Class: Women Transforming American Labor. Ithaca, NY: Cornell University Press.

Collins, Patricia Hill. 2000. "Gender, Black Feminism, and Black Political Economy." Annals of the American Academy of Political and Social Science 568(1): $41-53$.

Ferraro, Kathleen J., and Angela M. Moe. 2003. "Mothering, Crime, and Incarceration." Journal of Contemporary Ethnography 32(1):9-40.

Fishbein, Allen J., and Patrick Woodall. 2006. "Women Are Prime Targets for Subprime Lending: Women Are Disproportionately Represented in High-Cost Mortgage Market." Study, December. Consumer Federation of America, Washington, DC.

Froud, Julie, Adam Leaver, and Karel Williams. 2007. "New Actors in a Financialised Economy and the Remaking of Capitalism." New Political Economy 12(3):339-47.

Gill, Stephen. 2003. Power and Resistance in the New World Order. Houndmills: Palgrave Macmillan.

Gilmore, Ruth Wilson. 2007. Golden Gulag: Prisons, Surplus, Crisis, and Opposition in Globalizing California. Berkeley: University of California Press.

- 2009. "Race, Prisons, and War: Scenes from the History of U.S. Violence." Socialist Register 45:73-87.

Gruenstein, Debbie, Keith S. Ernst, and Wei Li. 2006. "Unfair Lending: The Effect of Race and Ethnicity on the Price of Subprime Mortgages." Report, May 31. Center for Responsible Lending, Durham, NC. http://www.responsiblelending .org/mortgage-lending/research-analysis/rr011-Unfair_Lending-0506.pdf. 
Haney, Lynne. 2004. "Introduction: Gender, Welfare, and States of Punishment." Social Politics 11(3):333-62.

Harvey, David. 2005. A Brief History of Neoliberalism. Oxford: Oxford University Press.

Heimer, Karen. 2000. “Changes in the Gender Gap in Crime and Women's Economic Marginalization.” In Criminal Justice, 2000, vol. 1, ed. Gary LaFree, 427-83. Washington, DC: National Institute of Justice. http://www.ncjrs .gov/criminal_justice2000/vol_1/02-front.pdf.

Human Rights Watch. 2001. "Hidden in the Home: Abuse of Domestic Workers with Special Visas in the United States." Human Rights Watch World Report 13(2). http://www.hrw.org/legacy/reports/2001/usadom/.

Langley, Paul. 2008. The Everyday Life of Global Finance: Saving and Borrowing in Anglo-America. Oxford: Oxford University Press.

LeBaron, Genevieve. 2008. "Captive Labour and the Free Market: Prisoners and Production in the USA." Capital and Class 95 (Summer): 59-81.

Lipman, Pauline. 2006. "The Politics of Education Accountability in a Post-9/11 World." Cultural Studies $\longleftrightarrow$ Critical Methodologies 6(1):52-72.

Lovell, Vicky, Heidi Hartmann, and Misha Weschkul. 2007. "More than Raising the Floor: The Persistence of Gender Inequalities in the Low-Wage Labor Market." In Cobble 2007, 35-58.

Marx, Karl. (1867) 1990. Capital: A Critique of Political Economy, vol. 1. Trans. Ben Fowkes. Toronto: Penguin.

McLean, Rachel L., and Michael D. Thompson. 2007. "Summary Report: Repaying Debts." Report. Bureau of Justice Assistance and the Council of State Governments Justice Center, New York. http://reentrypolicy.org/jc_publications/ repaying_debts_summary.

McNally, David. 2006. Another World Is Possible: Globalization and Anti-Capitalism. Rev. expanded ed. Winnipeg: Arbeiter Ring.

Misra, Joya, Jonathan Woodring, and Sabine N. Merz. 2006. "The Globalization of Care Work: Neoliberal Economic Restructuring and Migration Policy.” Globalizations 3(3):317-32.

Montgomerie, Johnna. 2009. "The Pursuit of (Past) Happiness? Middle-Class Indebtedness and American Financialisation." New Political Economy 14(1): $1-24$.

Morgenson, Gretchen. 2008. "Given a Shovel, Americans Dig Deeper into Debt." New York Times, July 20. http://www.nytimes.com/2008/07/20/business/ 20debt.html.

Mosley, Walter. 2009. “Ten Things You Can Do to Reduce Incarceration.” Nation, November 16, 8.

Munnell, Alicia H., and Mauricio Soto. 2008. "The Housing Bubble and Retirement Security." Brief no. 8-12, September. Center for Retirement Research, Boston. http://crr.bc.edu/images/stories/Briefs/ib_8-12.pdf.

Neocleous, Mark. 2000. The Fabrication of Social Order: A Critical Theory of Police Power. London: Pluto. 
O'Connor, Julia S., Ann Shola Orloff, and Sheila Shaver. 1999. States, Markets, Families: Gender, Liberalism, and Social Policy in Australia, Canada, Great Britain, and the United States. New York: Cambridge University Press.

Orloff, Ann Shola. 1993. "Gender and the Social Rights of Citizenship: The Comparative Analysis of Gender Relations and Welfare States." American Sociological Review 58(3):303-28.

Panitch, Leo. 2004. "Globalization and the State." In The Globalization Decade: A Critical Reader, ed. Leo Panitch, Colin Leys, Alan Zuege, and Martijn Konings, 9-43. London: Merlin.

Panitch, Leo, and Sam Gindin. 2004. Global Capitalism and American Empire. London: Merlin.

Parenti, Christian. 1999. Lockdown America: Police and Prisons in the Age of Crisis. London: Verso.

Parreñas, Rhacel Salazar. 2001. "Transgressing the Nation-State: The Partial Citizenship and 'Imagined (Global) Community' of Migrant Filipina Domestic Workers." Signs: Journal of Women in Culture and Society 26(4):1129-54.

Pew Center on the States. 2008. "One in 100: Behind Bars in America 2008." Report. Pew Charitable Trusts, Washington, DC.

- 2009. "One in 31: The Long Reach of American Corrections." Report, March. Pew Charitable Trusts, Washington, DC.

Picchio, Antonella. 1992. Social Reproduction: The Political Economy of the Labour Market. Cambridge: Cambridge University Press.

Pollin, Robert. 1990. Deeper in Debt: The Changing Financial Conditions of U.S. Households. Washington, DC: Economic Policy Institute.

Pyle, Jean. 2006. "Globalization and the Increase in Transnational Care Work: The Flip Side." Globalizations 3(3):297-315.

Ruggie, John Gerard. 1982. "International Regimes, Transactions, and Change: Embedded Liberalism in the Postwar Economic Order." International Organization 36(2):379-415.

Sassen, Saskia. 2002. "Women's Burden: Counter-Geographies of Globalization and the Feminization of Survival." Nordic Journal of International Law 71(2): $255-74$.

Soederberg, Susanne. 2007. "Freedom, Ownership, and Social (In-)Security in the United States." Cultural Critique 65:94-114.

Sudbury, Julia, ed. 2005. Global Lockdown: Race, Gender, and the Prison-Industrial Complex. New York: Routledge.

Vosko, Leah. 2006. "Crisis Tendencies in Social Reproduction: The Case of Ontario's Early Years Plan." In Bezanson and Luxton 2006, 145-72.

Wacquant, Loïc. 2001. "Deadly Symbiosis: When Ghetto and Prison Meet and Mesh." Punishment and Society 3(1):95-133.

- 2002. "Four Strategies to Curb Carceral Costs: On Managing Mass Imprisonment in the United States." Studies in Political Economy 69 (Autumn): 19-30. 
LeBaron and Roberts

Western, Bruce. 2006. Punishment and Inequality in America. New York: Russell Sage.

Western, Bruce, and Katherine Beckett. 1999. "How Unregulated Is the U.S. Labor Market? The Penal System as a Labor Market Institution." American Journal of Sociology 114(4):1030-60. 